\title{
Automatic Text Summarization Berdasarkan Pendekatan Statistika pada Dokumen Berbahasa Indonesia
}

\author{
Christopher Setyawan ${ }^{1 *}$, Njoto Benarkah ${ }^{1}$, Vincentius Riandaru Prasetyo ${ }^{1}$ \\ ${ }^{1}$ jurusan Teknik Informatika Fakultas Teknik, Universitas Surabaya, Raya Kalirungkut Surabaya-Indonesia \\ 60293 \\ * corresponding author: christopher1setyawan@gmail.com
}

\begin{abstract}
Propelled by the modern technological innovations data and text will be more abundant throughout the year. With this much text, automatic text summarization is needed now more than ever to help summarize a text. Automatic text summarization is defined as the creation of a shortened version of a text by a computer program, the product of this procedure still contains the most important points of the original text. Statistical approaches is one of automatic text summarization method. There is 5 statistical approaches that being used namely aggregation similarity method, frequency method, location method, title method (if text has a title), dan tf-based query method (if text doesn't have a title). Cosine similarity is used to calculate title method, aggregation similarity method, and tf-based query method. There is two type of validation, user validation and system validation. For system validation compare the similarity between human summary and summary generated by program, which result in accuracy of $76.7647 \%$ for summary with $30 \%$ length of the original journal. For user validation result in $82 \%$ accuracy. The conclusion based on user validation and system validation is statistical approaches is suitable for automatic text summarization.
\end{abstract}

Keywords: automatic text summarization, statistical approaches, Indonesian document, cosine similarity

\begin{abstract}
Abstrak- Dengan kemajuan teknologi jumlah data dan teks akan semakin melimpah sepanjang tahun. Dengan banyaknya teks ini dibutuhkan bantuan automatic text summarization untuk merangkum teks tersebut. Automatic text summarization didefinisikan sebagai versi singkat dari suatu teks menggunakan program komputer yang hasilnya masih memiliki informasi penting berupa gagasan dasar dan kata atau kalimat yang dapat merepresentasikan keseluruhan teks original. Salah satu metode dalam automatic text summarization adalah pendekatan statistika. Pendekatan statistika yang digunakan ada 5 yaitu aggregation similarity method, frequency method, location method, title method (bila teks memiliki judul), dan tf-based query method (bila teks tidak memiliki judul). Cosine similarity dipakai untuk perhitungan title method, tf-based query method, dan aggregation similarity method. Validasi dilakukan dengan dua macam validasi. Pertama adalah validasi sistem dengan membandingkan similaritas antara rangkuman program dan rangkuman manusia, yang menghasilkan akurasi $76.7647 \%$ untuk rangkuman dengan panjang $30 \%$ dari jurnal original. Kedua adalah validasi user yang menghasilkan akurasi $81 \%$. Kesimpulannya berdasarkan validasi user dan validasi sistem yang cukup baik maka pendekatan statistika cocok dipakai dalam kasus automatic text summarization.
\end{abstract}

Kata kunci: automatic text summarization, pendekatan statistika, cosine similarity, dokumen berbahasa Indonesia

\section{PENDAHULUAN}

Manuel dan Moreno (2014) menuliskan automatic text summarization menurut definisi kamus Oxford adalah versi singkat dari suatu teks menggunakan program komputer yang hasilnya masih memiliki informasi penting berupa gagasan dasar dan kata atau kalimat yang dapat merepresentasikan keseluruhan teks original. Tujuan dari automatic text summarization adalah untuk membuat ringkasan yang singkat, mudah dipahami kalimatnya dan memiliki informasi penting yang ingin disampaikan dari teks original tersebut.

Dengan kemajuan teknologi yang semakin pesat, data dan teks akan semakin banyak dan melimpah seiring dengan bertambahnya tahun. (Garbade, 2018). Beberapa alasan mengapa diperlukannya automatic text summarization adalah mempersingkat waktu pembacaan, mempermudah proses seleksi, dan menghindari bias (Manuel dan Toreno, 2014). Alasan lainnya adalah karena automatic text summarization dapat merangkum teks-teks panjang dengan cepat dan akurat, suatu hal yang akan memakan waktu lama dan membutuhkan biaya besar bila dilakukan oleh manusia tanpa bantuan mesin. (Garbade, 2018). Berdasarkan hasil wawancara juga didapatkan hasil bahwa narasumber memiliki masalah saat ingin memahami dan mencari inti suatu teks dan masalah waktu baik dari waktu untuk memahami maupun waktu untuk merangkum. 
Pada automatic text summarization terdapat istilah kompresi $\tau$ yang didapatkan dari rasio perbandingan panjang rangkuman dan panjang teks original, panjang teks ini bisa berarti karakter, kata, ataupun kalimat. Hasil automatic text summarization terbaik ditemukan saat kompresi $\tau=15$ sampai dengan $30 \%$ dari panjang teks original atau kurang dari sepertiga panjang teks original (Manuel dan Moreno, 2014).

Ada dua macam automatic text summarization yaitu metode extractive dan metode abstractive. Metode extractive adalah metode yang mengambil kata atau kalimat pada teks original kemudian memberikan ringkasan, pada teknik ini tidak ada perubahan kata atau kalimat pada teks. Sedangkan metode abstractive adalah metode yang memberikan kata baru yang tidak ada pada teks original lalu menggabungkan dan menyusun kata baru tersebut dengan kata-kata original untuk membuat kalimat baru dan memberikan ringkasan dari kalimat-kalimat baru tersebut. (Garbade, 2018). Pendekatan statistika adalah metode extractive.

Sebelum dilakukan pendekatan statistika langkah pertama yang perlu dilakukan adalah preprocessing. Prepoccessing yang digunakan adalah segmentasi, stemming, stopword, dan tokenizing. Segmentasi adalah memecah teks menjadi paragraf, lalu dari paragraf dipecah menjadi kalimat nantinya hasil rangkuman akan dikembalikan menjadi kalimat-kalimat asli dari segmentasi ini. Stemming digunakan untuk merubah kata dalam tiap kalimat hasil segmentasi menjadi kata dasarnya contoh kata perubahan menjadi kata ubah. Stopword digunakan untuk menghapus kata yang kurang penting atau irrelevant contoh kata ini, dari, ke, pada. Tokenizing merupakan proses untuk memisah kalimat menjadi kata.

Langkah selanjutnya setelah preprocessing adalah ekstrasi fitur. Ekstrasi fitur yang digunakan adalah term frequency raw (tf raw) dan term frequency - inverse document frequency (tf idf). Term frequency - inverse document frequency adalah perkalian dari term frequency row (tf raw) yang dipakai untuk menghitung jumlah kemunculan kata / term untuk tiap kalimat pada teks. Sedangkan inverse document frequency adalah perhitungan untuk menentukan bobot pada suatu kata / term dalam suatu teks. Nantinya hasil dari nilai ekstrasi fitur tf-idf ini digunakan untuk perhitungan similaritas, dan untuk beberapa metode dalam pendekatan statistika.

Similaritas dalam pendekatan statistika digunakan untuk menghitung kemiripan antara kalimat dengan kalimat lainnya, atau kalimat dengan judul. Similaritas yang digunakan adalah cosine similarity. Untuk proses perhitungannya didapatkan dari nilai-nilai dari ekstrasi tf-idf sebelumnya.

Metode pendekatan statistika yang digunakan ada 5 yaitu title method, location method, aggregation similarity method, freguency method, tf-based query method (Ko dan Seo, 2008). Title method dilakukan apabila teks memiliki judul, skor tiap kalimat dilakukan dengan perhitungan similaritas antara judul dengan masing -masing kalimatnya menggunakan cosine similarity. Tf-based query method akan dilakukan apabila teks tidak memiliki judul. Katakata yang memiliki jumlah frekuensi kemunculan tertinggi dalam teks akan dipilih untuk menggantikan fungsi judul, kemudian skor kalimat akan dihitung dari similaritas antara kalimat dengan kata-kata yang menggantikan judul ini. Bila metode ini dipakai title method tidak akan digunakan dan juga sebaliknya. Pada aggregation similarity method skor kalimat akan dihitung dari total similaritas satu kalimat dengan seluruh kalimat lainnya yang ada pada teks tersebut. Pada frequency method dihitung skor bobot suatu kalimat dari total bobot tiap kata yang dimiliki oleh suatu kalimat, bobot ini didapatkan dari tf-idf. Pada location method akan memberikan skor tiap kalimat terhadap lokasi kalimat dalam sebuah teks, biasanya kalimat pada awal teks lebih penting dan dapat menjadi ringkasan yang baik sehingga memiliki skor yang lebih tinggi. Terakhir dari ke 4 metode yang akan dipakai untuk merangkum teks tersebut akan dihitung skor akhirnya untuk masing-masing kalimat. Kalimat yang memiliki skor akhir tinggi inilah yang akan dijadikan hasil rangkuman. 


\section{METODE}

Metode penelitian dilakukan dengan menganalisa keadaan saat ini, analisa sistem sejenis dan kebutuhan sistem. Keadaan saat ini dianalisa dengan melakukan wawancara terhadap 3 mahasiswa dan 1 guru SD. Dari narasumber mengatakan pernah menemui teks yang cukup panjang dalam perkuliahan atau saat mengajar dan pernah mengalami masalah dalam memahami teks tersebut. Keempat dari narasumber mengatakan biasanya membuat rangkuman terlebih dahulu untuk memahami suatu teks, setelah selesai merangkum kemudian narasumber juga akan menghafal dan mempelajari materi dari hasil rangkumanya. Ada 2 narasumber yang mengatakan cukup sulit untuk memahami inti teks dan malas saat ingin merangkum. Keempat dari narasumber mengeluhkan tentang waktu yang cukup lama untuk memahami teks lalu merangkum kemudian mempelajarinya lagi. Kesimpulan inti dari permasalah-permasalahan narasumber adalah tentang waktu dan memahami serta mencari inti materi.

Analisis sistem sejenis yang dibahas menggunakan penelitian yang berkaitan dengan automatic text summarization dengan menggunakan beberapa macam metode. Penelitian pertama oleh Tardan, Erwin, Eng dan Muliady (2013), dengan membandingkan hasil metode semantic dengan euclidean, semantic dengan cosine dan pendekatan statistika dengan word frequency dan pendekatan statistika dengan jaccard. Pendekatan statistika yang digunakan adalah title method dan location method. Hasilnya kompresi dengan pendekatan statistika memiliki nilai tertinggi, tetapi semantic memiliki tingkat hasil subjektivitas lebih tinggi.

Penelitian kedua dilakukan oleh Kyoomarsi, Khosravi, Eslami, \& Davoudi (2010). Metode yang digunakan adalah fuzzy logic dengan menggunakan Mamdani. Kesimpulan yang didapatkan peneliti adalah kelebihan dari metode yang dipakai adalah hasil rangkuman lebih mirip dengan rangkuman manusia, dan kelemahannya adalah proses untuk mendesain variabel dan rules sangat memakan waktu.

Penelitian ketiga dilakukan oleh Darmawan \& Wahono (2015). Metode yang digunakan adalah ekstraksi kata kunci dengan nilai tf-idf dan menggabungkanya dengan cosine similarity. Kesimpulan yang didapatkan oleh peneliti adalah penggunaan cosine similarity dapat meningkatkan kepaduan antar kalimat pada rangkuman, meningkatkan hasil rangkuman dan kompresi terbaik yang didapatkan dari hasil percobaan adalah $50 \%$.

Dari permasalahan diatas akan dibuat suatu program automatic text summarization untuk mempersingkat waktu dan memudahkan user dalam memahami teks. User hanya perlu meng-upload file yang ingin dirangkum atau copy paste pada bagian yang disediakan atau mengetik manual teks yang ingin dirangkum. Program akan menggunakan pendekatan statistika dengan cosine similarity.

\section{HASIL DAN PEMBAHASAN}

Pada tahap ini dilakukan desain dan implementasi program, kemudian dilakukan ujicoba yaitu verifikasi dan validasi untuk mengetahui tingkat akurasi program dalam pembuatan rangkuman.

Desain pembuatan automatic text summarization meliputi desain database, desain proses, dan desain antarmuka. Untuk ERD karena automatic text summarization sebenarnya tidak perlu disimpan dalam database, maka database hanya akan berjalan apabila user login ke sistem, dan hanya digunakan untuk menyimpan data user dan history rangkuman yang dilakukan oleh user, proses inti automatic text summarization tidak membutuhkan database dapat dilihat pada Gambar 1.

Untuk desain proses pertama saat user masuk kedalam website, user bisa login atau tidak. Apabila user ingin merangkum maka setelah user memasukkan input teks atau file dan judul (opsional) prosesnya adalah menunggu sistem selesai merangkum. Pada proses ini dicek terlebih dahulu apakah format file benar atau adakah teks yang dikirim (txt, docx) apabila format tidak benar akan ditampilkan pesan error. Apabila format benar dilakukan proses automatic text summarization mulai dari preprocessing, ekstraksi fitur, perhitungan cosine 
similarity, dan metode yang dipakai dalam pendekatan statistika. Setelah itu sistem akan menampilkan hasil rangkuman yang telah dibuat. Apabila pada awal user login hasil rangkuman akan disimpan dalam database, dan user dapat melihat riwayat rangkuman yang sudah dirangkum oleh user tersebut. Dapat dilihat pada Gambar 2 dan Gambar 3. Untuk user interface halaman awal tanpa login dapat dilihat pada Gambar 4.

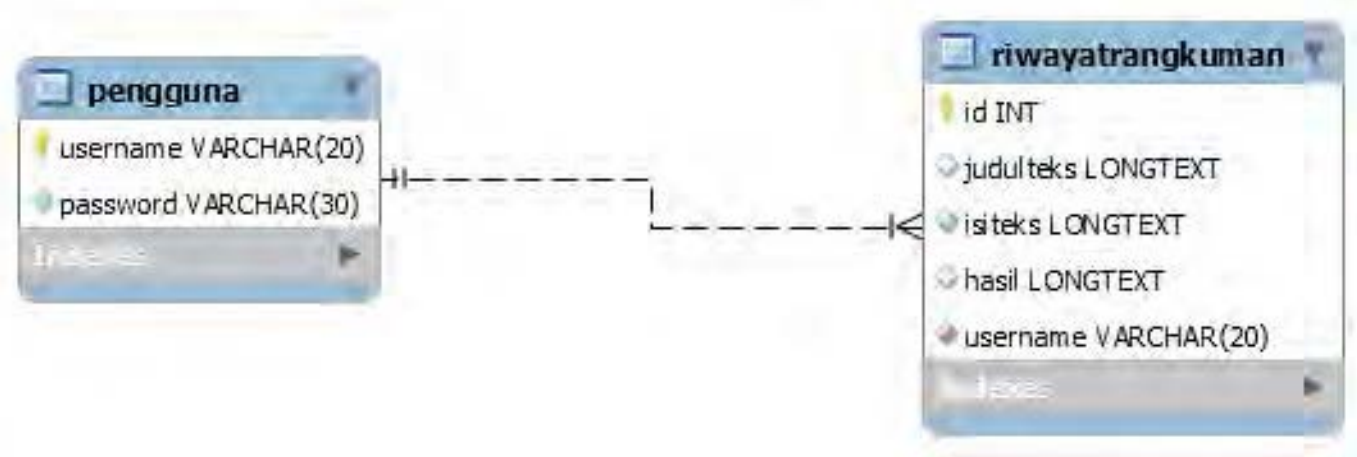

Gambar 1. ERD program automatic text summarization.

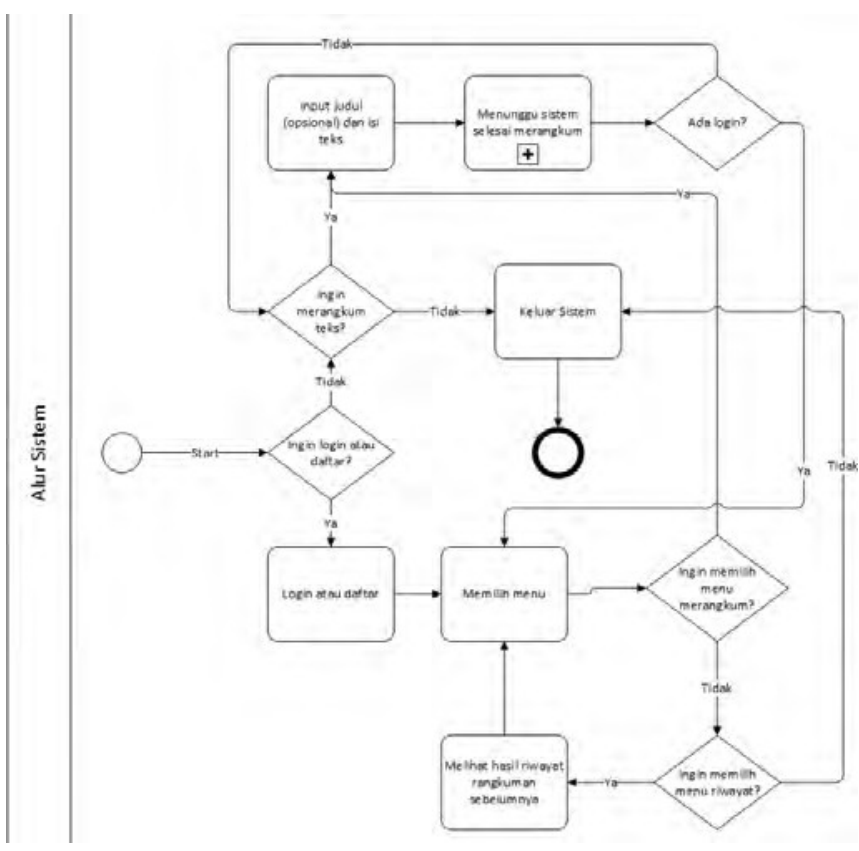

Gambar 2. Desain proses alur pengguna. 


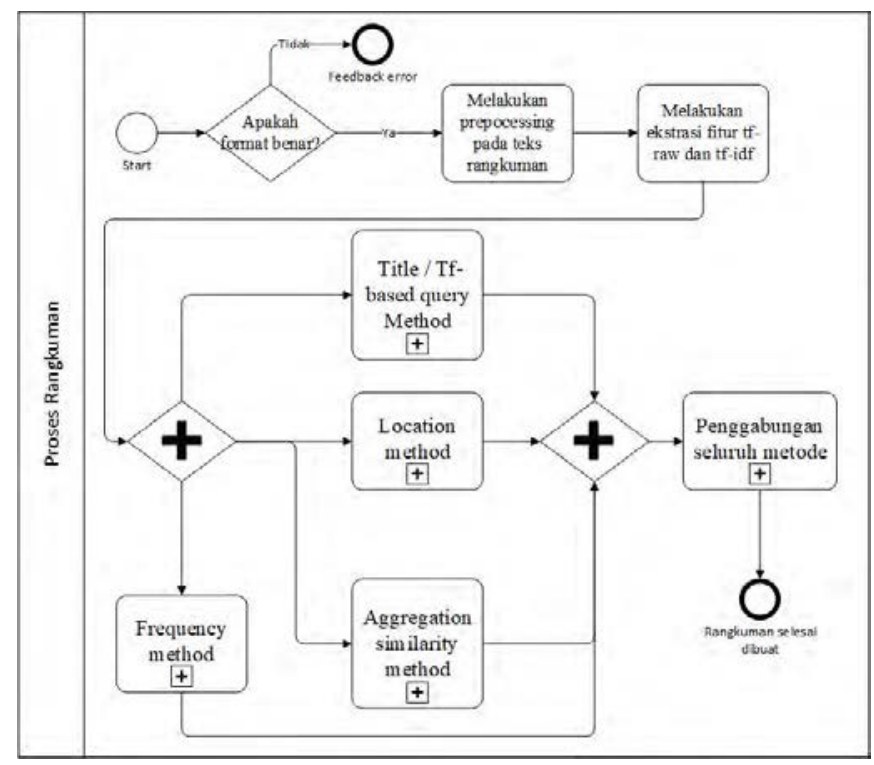

Gambar 3. Desain proses rangkuman sistem.

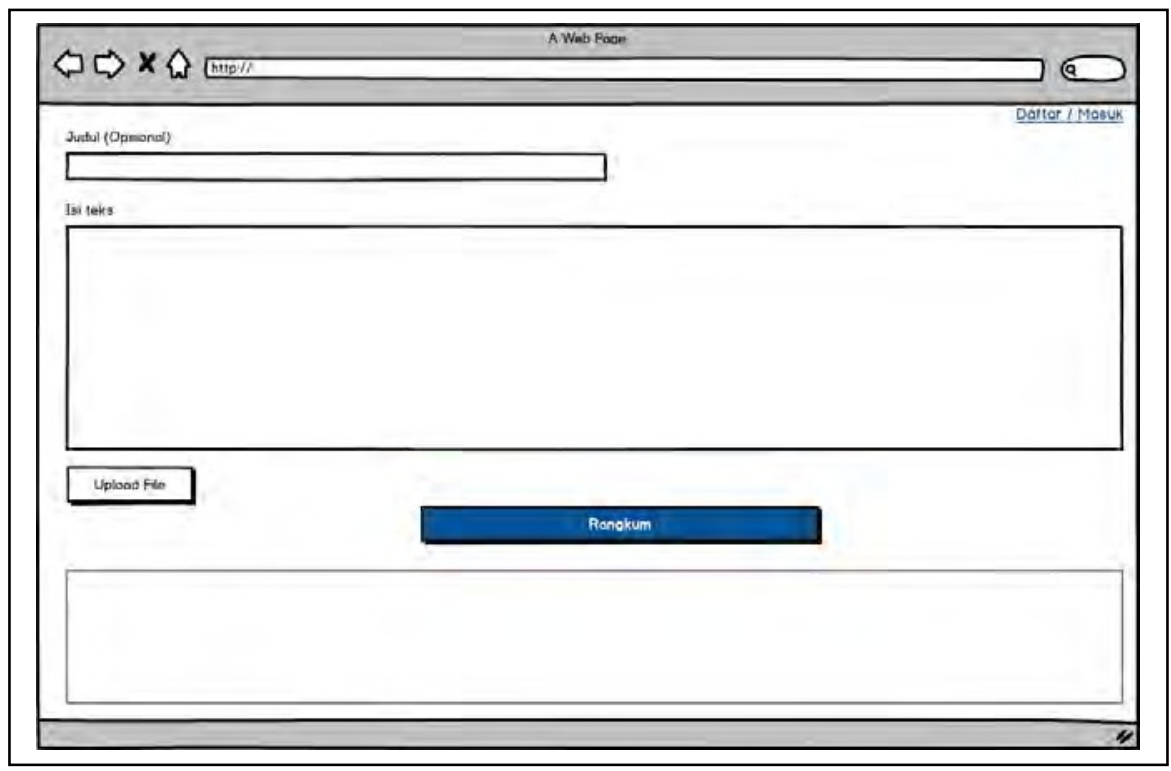

Gambar 4. Desain user interface halaman awal.

Implementasi sistem menggunakan bahasa pemrograman PHP. Database dibuat dengan MySql. Verifikasi pengecekan metode perhitungan manual dengan hasil rangkuman yang dibuat oleh program. Untuk validasi ada 2 yaitu validasi sistem dan validasi user. Pada validasi sistem dilakukan dengan memilih 10 teks yang akan dihitung kemiripannya antara rangkuman manusia dengan hasil rangkuman yang dibuat oleh program. Pada validasi user dilakukan dengan meminta 10 user untuk memilih teks/ dokumen yang ingin dirangkum, kemudian menilai dari rentang 0-10 hasil rangkuman yang dibuat oleh program, apakah menurut user hasil rangkuman memuaskan, memiliki informasi penting dan inti teks dan apakah menurut user cukup singkat. Rata-rata dari validasi user adalah $81 \%$ dan rata-rata cukup puas dengan hasil rangkuman. Selanjutnya juga dibandingkan validasi user jika memakai title method dan location method saja menggunakan data teks dan user yang sama seperti saat dilakukan validasi user asal. Terakhir perbandingan dengan semantic untuk 1 data teks percobaan dengan meminta 10 user menilai hasil dari 2 rangkuman tersebut. 
Pada validasi sistem dibandingkan antara hasil rangkuman 15\%, 20\%, 25\%, dan 30\% dari teks original untuk menentukan tingkat kompresi yang memiliki hasil paling baik. Hasil rangkuman ini akan dihitung similaritasnya dengan rangkuman yang dibuat oleh manusia. Hasilnya dapat dilihat pada tabel 1.

Tabel 1

Hasil Validasi Sistem

\begin{tabular}{|c|c|c|c|c|}
\hline Teks Ke- & $\begin{array}{c}\text { Similaritas } \\
\text { rangkuman } 15 \% \\
\text { dan rangkuman } \\
\text { manusia }\end{array}$ & $\begin{array}{c}\text { Similaritas } \\
\text { rangkuman } 20 \% \\
\text { dan rangkuman } \\
\text { manusia }\end{array}$ & $\begin{array}{l}\text { Similaritas } \\
\text { rangkuman } \\
25 \% \text { dan } \\
\text { rangkuman } \\
\text { manusia }\end{array}$ & $\begin{array}{c}\text { Similaritas } \\
\text { rangkuman } 30 \% \\
\text { dan rangkuman } \\
\text { manusia }\end{array}$ \\
\hline 1 & 0.641963 & 0.641963 & 0.6959227 & 0.7135533 \\
\hline 2 & 0.7381301 & 0.8000847 & 0.8153694 & 0.814961 \\
\hline 3 & 0.5282002 & 0.5282002 & 0.6542861 & 0.6925869 \\
\hline 4 & 0.8315932 & 0.8669614 & 0.8773525 & 0.8909504 \\
\hline 5 & 0.6342576 & 0.685882 & 0.7609974 & 0.7741126 \\
\hline 6 & 0.7335139 & 0.7264132 & 0.7877683 & 0.8080817 \\
\hline 7 & 0.5278007 & 0.5732882 & 0.6087139 & 0.6376366 \\
\hline 8 & 0.5422262 & 0.5713861 & 0.6461512 & 0.6850196 \\
\hline 9 & 0.7055405 & 0.7193056 & 0.8040864 & 0.7998335 \\
\hline 10 & 0.8276997 & 0.8426774 & 0.8469788 & 0.8597309 \\
\hline $\begin{array}{l}\text { Rata- } \\
\text { rata }\end{array}$ & 0.67109251 & 0.69561618 & 0.74976267 & 0.76764665 \\
\hline
\end{tabular}

Dari hasil tabel 6.7 maka untuk hasil rangkuman dengan panjang 15\% memiliki ratarata nilai similaritas 0.67109251 yang berarti memiliki tingkat akurasi $67.1093 \%$. Untuk hasil rangkuman dengan panjang $20 \%$ memiliki rata-rata nilai similaritas 0.69561618 yang berarti memiliki tingkat akurasi $69.5616 \%$. Untuk hasil rangkuman dengan panjang $25 \%$ memiliki ratarata similaritas 0.74976267 yang berarti memiliki tingkat akurasi $74.9763 \%$. Terakhir untuk hasil rangkuman dengan panjang $30 \%$ memiliki rata-rata similaritas 0.76764665 yang berarti memiliki akurasi sebesar $76.7647 \%$. Berdasarkan hasil percobaan tersebut menandakan rangkuman dengan panjang $30 \%$ yang paling bagus untuk digunakan dalam rangkuman. Hasil percobaan juga menunjukkan bahwa untuk validasi sistem didapatkan hasil yang cukup memuaskan.

Untuk validasi user jika menggunakan title method dan location method didapatkan akurasi $65 \%$ lebih rendah dari validasi user yang memiliki akurasi $81 \%$. Maka penggunaan penggabungan title method/ tf-based query method, location method, frequency method, aggregation similarity method terbukti lebih meningkatkan akurasi hasil rangkuman dibandingan dengan penggunaan title method dan location method. Untuk validasi perbandingan dengan semantic didapatkan hasil akurasi $76 \%$ untuk semantic dan $78 \%$ untuk program. Dari pendapat user didapatkan hasil bahwa semantic lebih unggul di segi kesinambungan kalimat dan lebih berurutan, sedangkan pendekatan statistika yang digunakan program lebih unggul di segi kalimat yang lebih dianggap penting dan berbobot, serta informasi yang lebih jelas.

\section{SIMPULAN}

Dari hasil uji coba dan evaluasi didapatkan kesimpulan dan saran. Berdasarkan hasil validasi user memiliki nilai rata-rata $81 \%$. Berdasarkan hasil validasi sistem hasil terbaik ada pada rangkuman dengan panjang $30 \%$ dari jurnal asli dengan nilai rata-rata $76.7647 \%$. Penggunaan penggabungan title method/ tf- based query method, location method, 
aggregation similarity method, dan frequency method dapat meningkatan akurasi rangkuman. Berdasarkan pendapat user hasil rangkuman semantic lebih unggul di segi kesinambungan kalimat dan kalimat lebih beruntun, sedangkan hasil rangkuman pendekatan statistika lebih unggul di segi informasi yang lebih jelas dan kalimat yang lebih penting.

Saran dapat ditambah atau digabungkan dengan metode semantic untuk meningkatkan kesinambungan antar kalimatnya. Bisa juga digabungkan dengan metode lainnya yang bisa merangkai kalimat sendiri dengan mengambil hanya beberapa kata penting dalam kalimat asal sehingga rangkuman lebih lagi memiliki kesinambungan dan lebih seperti hasil rangkuman manusia. Lalu menggunakan suatu metode untuk mengenali rujukan kata, agar kata rujukan yang seharusnya mengacu pada kata di kalimat sebelumnya menjadi jelas dan tidak rancu.

\section{PUSTAKA ACUAN}

Darmawan, R., \& Wahono, R. S. (2015). Hybrid Keyword Extraction Algorithm and Cosine Similarity for Improving Sentences Cohesion in Text Summarization. Journal of Intelligent Systems, 1(2), 109 - 114. Retrieved from http://journal.ilmukomputer.org/index.php/jis/ article/view/44

Garbade, M. J. (2018, September 19). A Quick Introduction to Text Summarization in Machine Learning. Retrieved from https://towardsdatascience.com/a- quick-introduction-to-textsummarization-in-machine-learning-3d27ccf18a9f

Ko, Y., \& Seo, J. (2008). An effective sentence-extraction technique using contextual information and statistical approaches for text summarization. Pattern Recognition Letters, 29(9), 1366 - 1371. DOI: 10.1016/j.patrec.2008.02.008

Kyoomarsi, F., Khosravi, H., Eslami, E., \& Davoudi, M. (2010). Extraction-based text summarization using fuzzy analysis. Iranian Journal of Fuzzy System, 7(3), 15 - 32. DOI: 10.1007/978-3-540-79187-4_11

Manuel,J., \& Moreno, T. (2014). Automatic Text Summarization. DOI:10.1002/9781119004752

Tardan, P. P., Erwin, E., Eng, K. I., \& Muliady, W. (2013). Automatic Text Summarization Based on Semantic Analysis Approach for Documents in Indonesia Languange. 2013 International Conference on Information Technology and Electrical Engineering (ICITEE), 47 - 52. DOI: 10.1109/ICITEED.2013.6676209 